\title{
SELF-DIRECTED CROSS-CURRICULUM TEACHING/LEARNING PROCESS FROM THE PERSPECTIVE OF PARADIGM SHIFT
}

\author{
Anita Petere \\ Riga Teacher Training and Educational Management Academy, Latvia
}

\begin{abstract}
The strategy of a sustainable development of Latvia until year 2030 marks a significant trend - creativity and talents as competitiveness. The key words of the progress of education policy can be characterized as learning together - pupil and pupil, pupil and teacher, teacher and teacher, building a supportive and creative environment in teaching/learning process.

On the basis of the above mentioned, a paradigm shift clearly emerges in school pedagogical process. It can be characterized as learning by doing - changing the achievement evaluation system, providing pupils' understanding to influence and guide the study process themselves according to their interests and needs for personality development.

The essence of the research reveals the correlations between a self-directed cross-curriculum teaching/learning process of early school age pupils and the implementation of the paradigm focused on a pupil's learning activity.

The sources of self-development and a self-directed teaching/learning process lie in action itself. An action has its direction and the meeting of learning needs emerges in this direction.

The research reveals that a successful, self-directed teaching/learning process, based on theoretical conclusions, provides the implementation of the paradigm focused on a pupil's learning activity and meeting the pupil's learning needs. In its turn, the necessity for a further advance of the research emerges in order to discover pedagogical means for the motivation of teachers-practitioners to change their conventional style of work and see the advantages of the paradigm focused on a pupil's learning activity for the progress of personality development.
\end{abstract}

Keywords: cross-curriculum studies, learning activity skills, self-directed teaching and learning process.

\section{Introduction}

Paradigm change in education shows that a new social order for school can be formulated in the following way- to raise a free, critically and independently thinking person who is able to carry out intellectual searches and propose creative solutions. The execution of such order requires the overview of each teacher's philosophical approach to the organization of teaching/learning and pedagogical process. It means getting rid of the prevailing belief at school that a teacher is the main driver of the teaching/learning process and the key indicator 
is the pupils' obtained knowledge in school subjects. This means the abandonment of conventional teaching/learning plans where the teacher's planned results are already envisaged in advance. How can we explain the paradigm in education?

Žogla interprets a paradigm as philosophical understandingabout the pedagogical process, its efficiency: "A pedagogical paradigm is philosophical understanding about the pedagogical process, its efficiency. A paradigm is based on a certain approach and theory, it embraces specific values, aims and means to achieve them, expresses a teacher's or scientist's understanding about the characteristics of mutual correlation between the components of the pedagogical process (Žogla, 2001).

In education, when its objectives change, also the content, relationship and manifestation of other elements change. Thus, the whole paradigm changes. Pupils' learning is prior, a teacher's function is changing from the provider of information to the conductor of pupils' learning (Bluma, 2004). Learning itself means raising awareness about things and phenomena which were not known before. It is a process and work to be done by a pupil him/herself.

In education, when its objectives change, also the content, relationship and manifestation of other elements change. Thus, the whole paradigm changes. It refers to both the pedagogical process at school and teaching/learning process in class.

This article uses the concept of integrated teaching/learning model in primary school for revealing the approach which manifests itself as the unity of multidisciplinary and transdisciplinary approach which envisages the meeting of pupils' learning needs, revelation of certain connections within the cognizable problem as the fundamental aspect. The essence of this approach is:

- looking for sense through a systemic action,

- positive emotions in learning process,

- a challenge for pupils to check their abilities while taking part in planning the teaching/learning process,

- expanding the learning experience beyond separate subjects,

- $\quad$ integration of content and skills ensuring pupils 'development, based on the inner logics of the development.

In this article, the integrated teaching/learning model is revealed as a selfdirected learning where a teacher's and a pupil's actions radically change.

The aim of the article - to analyze the developed methodological approach for implementing a self-directed learning in the integrated teaching/learning model. 


\section{Methodology}

The methodological framework of pupils' self-directed learning is built by action theory, the critical constructivist approach and the characteristics of a self-directed learning. (Леонтьев, 2005; Леонтьев, 2007; Klafki, 1995; Gibbons, 2002).

Human development and the development of teaching/learning process are based on the action.

Moreover, the motives and stimuli of the action are closely connected since stimuli in action can become a motive. This procedural connection is determined by action theory (Леонтьев, 2007).

The rational estimate of action result in terms of satisfaction makes sense for both the motive and action result (for reaching the aim). The possibility for a pupil to engage in planning thematical units, a thoughtful analytical activity facilitate the awareness of sense.

The resulting motive reveals a certain need for a pupil to set the aim of his action, thus, transferring it into an interesting and exciting activity (Леонтьев, 2005; Maslo, 2006).

Paradigm manifestation in the integrated teaching/learning model can be clarified as the pedagogical process focused on a pupil's activity and based on the understanding about the action as personal development foundation, the quality of which is determined by the needs of the action performer.

Figure 1 reveals the manifestation of integrated teaching/learning model for early school age pupils.

Attitude towards studies
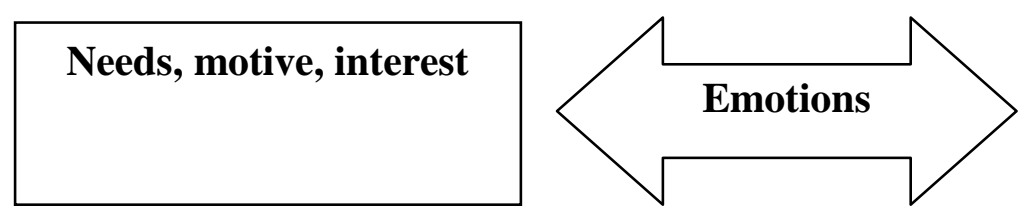

Generating ideas for thematical expansion

Learning activity (analysis, comparison, alteration, implementation of creative ideas, inference)

\begin{tabular}{|c|}
\hline Concentration, \\
excitement, interest, \\
setting the aim of the \\
action
\end{tabular}

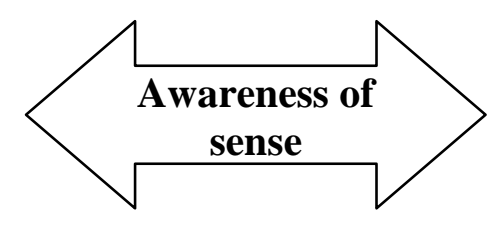

Defining the issue to be explored Active participation in planning

Evaluation, self-evaluation

Figure 1 Pupils' learning activity within integrated study model 
Fig. 1 shows that the teaching/learning process is based on positive emotions which ensure interest manifestation, the pupil's own active mental activity which is defined as emotional learning. The specifics of the teacher's and pupil's cooperation is shown in Table 1 .

\section{Table 1 Characteristics of cooperation between a teacher and a pupil}

Teaching/learning process focused on pupil's learning activity

\begin{tabular}{|l|l|}
\hline Pupil & Teacher \\
\hline $\begin{array}{l}\text { Engagement in discussing the } \\
\text { teaching/learning task }\end{array}$ & Reflection caused by the pupil's answers \\
\hline Proposes ideas, expresses needs & $\begin{array}{l}\text { Proposes information, shows where to look } \\
\text { for it }\end{array}$ \\
\hline $\begin{array}{l}\text { Finds information, analyzes, synthesizes, } \\
\text { groups, creatively transforms, concludes }\end{array}$ & $\begin{array}{l}\text { Organizes cooperation, helps to establish } \\
\text { criteria }\end{array}$ \\
\hline Carries out self-evaluation & $\begin{array}{l}\text { Evaluates pupils' activity, compares it with } \\
\text { self-evaluation }\end{array}$ \\
\hline
\end{tabular}

The above mentioned conclusions do not give a complete answer to what pupils' self-directed learning means.

Why self-directed learning? It helps pupils to control this thoughts, behavior, emotions, in order to successfully direct their own learning experience, develop their learning skills, a self-directed learning is controlled by mutually related factors which determine its development and sustainability and motivation is the most essential factor.

The self-directed learning offers teachers an innovative program for customizing schooling to the learning needs of individual students and for motivating them to take increasing responsibility for deciding what and how they should learn. Whether the students are struggling or proficient, the program is designed to nurture their natural passion for learning and mastery, challenging them to go beyond the easy and familiar so they can truly excel. Using this approach, the pupils take on an increasingly autonomous, self-directed role as they progress. The heart of the program is the action contract (or learning agreement) whereby the pupil sets challenging yet attainable goals, commits to a path for achieving them, and evaluates the results (Gibbons, 2002).

One of the most important tasks of the teacher is to raise student awareness of their roles in learning.

Learner participation in decision-making is another fundamental aspect of the SDL approach. S. Bolhuis supports involving students in decisions concerning what is to be learned, when and how it should be learned, and how it 
should be evaluated. In addition, every proponent of SDL emphasizes the importance of allowing learners to pursue their own interests so that learning becomes more meaningful.

Teachers who want to encourage SDL must free themselves from a preoccupation with tracking and correcting errors. S. Bolhuis advocated greater tolerance and encourages risk-taking, focuses on learners' strong points instead of weaknesses, as it is more beneficial for learners to achieve a few objectives of importance to them than it is to fulfill all the objectives that are important to the teacher (Bolhuis, 1996).

Figure 2 shows self- directed learning process.

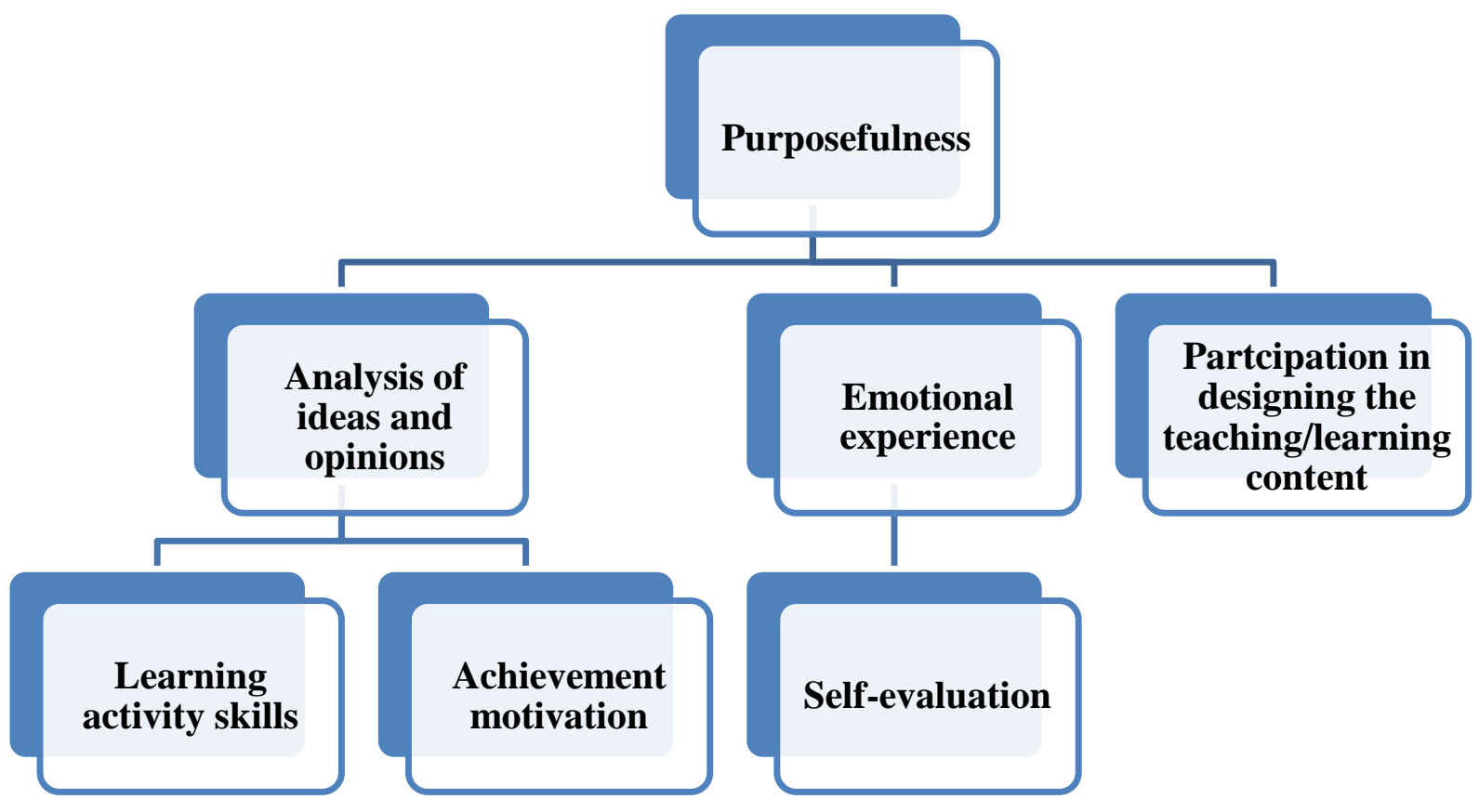

Figure 2 Self-directed learning

Purposefulness can arise when a pupil himself actively participates in the planning and implementation of teaching/learning is able to be aware of his desires and regulate both his learning and carry out reflection of his action. The creativity

As we can see from the figure, on the one hand, pupils participate in the creation of integrated teaching/learning content, on the other hand, the participation process comprises the features of a self-directed learning process. A pupil as a cooperation partner to a teacher, learns to substantiate and support his opinion, guide the development of cognizable issues, self-evaluate his performance and plan his learning activity. In order to develop a pupil's skill to self-direct the process, undoubtedly, the teacher's activity is of great importance. 
Important principles in teaching/ learning process:

- Good teaching cannot be reduced to techniques.

- Good teaching comes from the identity and the integrity of the teacher.

- Community in education is expressed through the interrelationships of teachers and learners.

Innovation comes in challenging, problematic classroom learning experience which emphasizes the independent voice of the child (Tarrant, 2015).

On the basis of the research carried out during the observation of integrated classes conducted by students, the conditions for organizing a self-directed learning process has been worked out. It comprises several mutually connected steps to guide the learning process. The implementation of this process is different for Form 1 or Form 3 pupil, and it also depends on a pupil's previous training. In case of need, also the pupils of Form 3 upon starting the implementation of a self-directed learning process, begin with the approach indicated for Form 1 pupils.

The conditions can be called as mutually connected implementation steps.

Table 2 Conditions for self-directed learning in Forms 1-4

Form 1, 2

Step 1

Pupils express their opinion what they would like to learn together with the teacher within one month. The answers usually comprise a wide range of topics, for instance, about animals, plants, euro, different people and even how to make soap (said by pupils)

Step 2

In order to use the mentioned answers over the whole planned period, the teacher writes down the answers on big sheets of paper, not on the board, so that during the process of exploring the topic which can take several days, pupils themselves could make sure about its guidance.

Step 3

Pupils learn to evaluate if all offered ideas will interest all pupils, or to some questions, such as "'how is soap made?', a pupil can find the answer by himself. It is vital to know why the pupil has offered such a question and how it is linked with the pupil's experience. 


\begin{abstract}
Step 4
The teacher's task is to help understand how a topical thematic unit is formed, for instance, the pupils have named animals, plants, but the teacher has suggested forming an interest hub- animals and plants in autumn.

In cooperation with the pupils, the issues to be explored are supplemented with the integrated teaching/learning content. For example, the pupils forecast what could be learnt about animals from the observed video. In the Latvian language - they themselves come to conclusion that they can reveal their feelings in the text designed by themselves. On the other hand, modeling the environment for the selected animal shows the acquisition of art design basics.
\end{abstract}

Form 3, 4

\title{
Step-1
}

A teacher offers a problem situation connected with the events in real life. For instance,.... On Sunday I was at the book exhibition and discovered that I do not know a lot about many books. What do you think, how we could organize book days in our class?

Step-2

In Forms 2, 3 and 4 children learn to work on the creation of an idea, thematic unit in small groups (in Form 2 they could be pairs). The number of pupils in a group should not be more than 4, otherwise the work will not be efficient, and it will not be possible to provide an active involvement of each pupil.

\section{Step-3}

It is vital for Step-3

It is vital for group work to set criteria i.e each pupil offers at least 1 idea.

In order to analyze the suggested ideas, venna diagramcould be successfullyapplied.

\section{Step-4}

To compare and evaluate the ideas of their own with the ideas of other groups, to find what recurs, what can be joined, how to order the ideas within a month.

\section{Step-5}

Planning the content of integrated studies. The teacher takes into consideration suggestions, but helps to define the task according to the acquisition of the necessary knowledge and skills in the particular form.

When exploring books, the pupils had a question about the difference in their prices. The pupils' task is to find the answer themselves to the question.

For instance, Why are book prices so different? With the help of mathematical tasks pupils learn to understand the contributions of various professions into the process of creation of a book. The teacher's task is to define the acquirable content in mathematics in order to explore this issue. 
Step-6

In accordance with the criteria designed by pupils, the pupils' self-evaluation is a vital condition in self-directed learning

\section{Conclusion}

The implementation of self-directed learning can be started already in Form 1 by creating conditions for pupils to acquire the simplest skills of independent learning, for example, suggesting ideas, a simple analysis of the suggested ideas, the connection of the ideas with own interests, supporting their thoughts.

Taking into consideration that in the research, the integrated teaching/learning content was applied, an important condition is teachers' skill to freely and creatively design thematic units of teaching/learning taking into account pupils' interests.

Implementation of the cooperation between the pupils and the teacher is an integral part of the above mentioned process. Only providing a purposefully conducted indirect cooperation, the pupils will be able to carry out selfevaluation of their action and design a plan for the further activities.

In further research, the methodology must be worked out to help teachers purposefully direct early school age children to implement SDL model.

\section{References}

Bolhuis, S. (1996). Towards Active and Self-directed Learning. Preparing for Lifelong Learning, with Reference to Dutch Secondary Education. Paper presented at the Annual Meeting of the American Educational Research Association (New York, NY, April 8$12,1996)$.

Bluma, D. (2004). Shift of Paradigms in Education. Riga:University of Latvia.

Gibbons, M. (2002). The self-directed Learning Handbook. Wiley.

Klafki, W. (1995). Didactic analysis as the core of preparation of instruction. Journal of Curriculum Studies, 27 (1), 13-30.

Maslo, I. (2006). No zināšanām uz kompetentu darbību [From knowledge to competent action]. Riga: LU Academic Publishing house, 13-34.

Tarrant, S. (2015). Innovative Teaching and Learning in Primary School. Singaporo: Washingtion DC

Žogla, I. (2001). Didaktikas teorētiskie pamati [Theoretical Basis of Didactics]. Riga: Publishing house Raka, 22.-46.

Леонтьев, А. Н. (1975/2005). Деятельность. Сознание. Личность [Action. Awareness. Personality]. Москва: Смысл, 346.

Леонтьев, Д. А. (2007). Психологиясмысла [Psychology of comprehension]. Москва: Смысл, 368. 